\title{
"The volatility effect across size buckets: evidence from the Indian stock market"
}

\begin{tabular}{|c|c|}
\hline AUTHORS & $\begin{array}{l}\text { Shilpa Peswani (D https://orcid.org/0000-0002-8418-1536 } \\
\text { Mayank Joshipura (D https://orcid.org/0000-0001-7711-6229 }\end{array}$ \\
\hline ARTICLE INFO & $\begin{array}{l}\text { Shilpa Peswani and Mayank Joshipura (2019). The volatility effect across size } \\
\text { buckets: evidence from the Indian stock market. Investment Management and } \\
\text { Financial Innovations, 16(3), 62-75. doi:10.21511/imfi.16(3).2019.07 }\end{array}$ \\
\hline DOI & http://dx.doi.org/10.21511/imfi.16(3).2019.07 \\
\hline RELEASED ON & Friday, 09 August 2019 \\
\hline RECEIVED ON & Wednesday, 12 June 2019 \\
\hline ACCEPTED ON & Monday, 08 July 2019 \\
\hline LICENSE & $\begin{array}{l}(\boldsymbol{c c}) \overline{\mathrm{EY}} \\
\text { This work is licensed under a Creative Commons Attribution } 4.0 \text { International } \\
\text { License }\end{array}$ \\
\hline JOURNAL & "Investment Management and Financial Innovations" \\
\hline ISSN PRINT & $1810-4967$ \\
\hline ISSN ONLINE & $1812-9358$ \\
\hline PUBLISHER & LLC "Consulting Publishing Company "Business Perspectives" \\
\hline FOUNDER & LLC "Consulting Publishing Company "Business Perspectives" \\
\hline
\end{tabular}

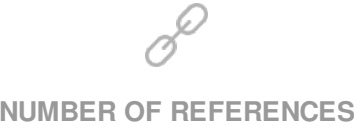

25

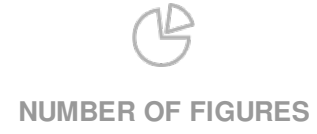

4

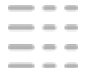

NUMBER OF TABLES

17

(C) The author(s) 2023. This publication is an open access article. 


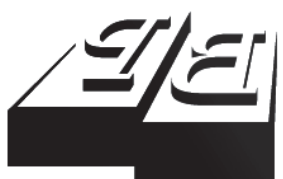

BUSINESS PERSPECTIVES

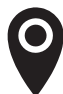

LLC "CPC "Business Perspectives" Hryhorii Skovoroda lane, 10, Sumy, 40022, Ukraine

www.businessperspectives.org

Received on: $12^{\text {th }}$ of June, 2019 Accepted on: $8^{\text {th }}$ of July, 2019

(C) Shilpa Peswani,

Mayank Joshipura, 2019

Shilpa Peswani, Assistant Professor, Faculty of Finance, St. Francis Institute of Management and Research affiliated to University of Mumbai, India.

Mayank Joshipura, Professor, Faculty of Finance, School of Business Management (SBM) of SVKM's NMIMS, Deemed to be University, India.

\section{(c) (i)}

This is an Open Access article, distributed under the terms of the Creative Commons Attribution 4.0 International license, which permits unrestricted re-use, distribution, and reproduction in any medium, provided the original work is properly cited.

\title{
THE VOLATILITY EFFECT ACROSS SIZE BUCKETS: EVIDENCE FROM THE INDIAN STOCK MARKET
}

\begin{abstract}
The portfolio of low-volatility stocks earns high risk-adjusted returns over a full market cycle. The annual alpha spread of low versus high-volatility quintile portfolios is $25.53 \%$ in the Indian equity market for the period from January 2000 to September 2018. The low-volatility (LV) effect is not an overlap of other established factors such as size, value or momentum. The effect persists across various size buckets (market capitalization). The performance of the low-volatility effect within various size buckets is analyzed using three different portfolio formation methods. Irrespective of the method of portfolio construction, the low-volatility effect exists and it also generates economically and statistically significant risk-adjusted returns. The long-short portfolios across the study deliver exceptionally high and statistically significant returns accompanied by negative beta. The low-volatility effect is not restricted to small or illiquid stocks. The effect delivers the highest risk-adjusted returns for the portfolio consisting of largecap stocks. Though the returns of the portfolio comprising of large-cap LV stocks are lower than the returns of the portfolio comprising of small-cap LV stocks, its Sharpe ratio is higher because of less risky nature of large-cap stocks as compared to small-cap stocks. The LV portfolio majorly comprises large-cap, growth and winner stocks. But within size buckets, large-cap and mid-cap low LV picks growth and winner stocks, while small-cap LV picks value stocks.
\end{abstract}

\section{Keywords}

\section{JEL Classification G11, G12, G14, G15}

\section{INTRODUCTION}

India is the world's third largest economy in terms of purchasing power parity. According to Asian Development Bank (ADB), it is the world's fastest growing major economy with 7.3\% growth rate in 2018-2019. Its progress is buttressed by dynamic reforms in the macroeconomic, fiscal, tax and business environments. It is seeking to achieve better growth by reshaping the policy approaches to human development, social protection, financial inclusion, rural transformation and infrastructure development. It is the dominant economy in the South Asia sub-region with its growth gaining momentum. Foreign Portfolio/ Institutional Investors (FPI/FII) have been one of the biggest drivers of India's financial markets and have invested around USD 172 billion in India between FY0218. Highly developed primary and secondary markets have attracted the FIIs/FPIs in India. They are regulated by Securities Exchange Board of India (SEBI). Even the Indian mutual fund industry has shown an exponential growth in investment since 2003 (see Figure 1).

FIIs are investing in India via hedge funds, foreign mutual funds, sovereign wealth funds, pension funds, trusts, asset management companies, endowments, university funds, etc. In March 2019, the Initial 


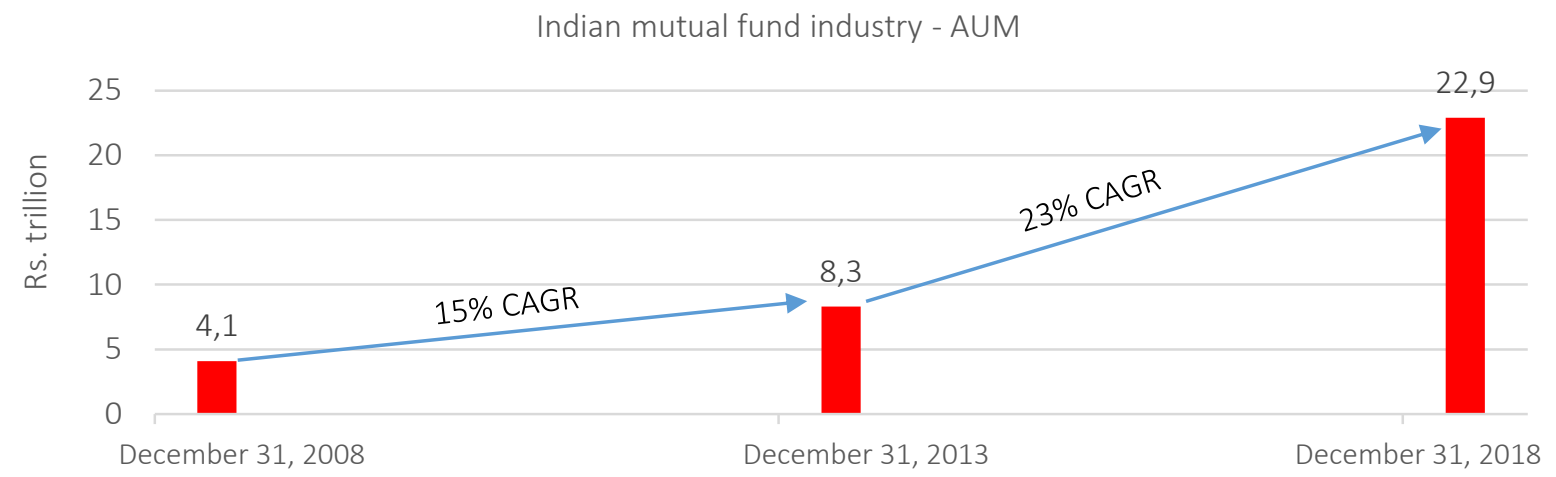

Figure 1. Indian mutual fund industry - assets under management

Public Offering (IPO) of India's first real estate investment trust (REIT) was subscribed 2.6 times. In February 2019, FPI in India reached USD 2.49 billion. A report filed by a panel appointed by SEBI on December 4, 2018 has proposed direct overseas listing of Indian companies and other regulatory changes. It relaxed the Know-Your-Client (KYC) requirement for FPIs. It is also proposed to allow non-resident Indians (NRIs) to invest through FPI route in commodity derivatives. FIIs investments have been strong and are expected to continue to improve going forward. Mr. Mark Machin, CEO, Canada Pension Plan Investment Board, has expressed confidence in the Indian equity market and stated that the country is one of the best investment destinations based on its demographic growth, increased productivity and long-term economic growth potential. The National Stock Exchange (NSE) is a leading stock exchange in India. It is the fourth largest in the world by equity trading volume. In May 2019, NSE has a market capitalization of USD 2.2 trillion, an average daily turnover of USD 5189.67 million and the number of companies listed is 1,942. These facts demonstrate the robustness and liquidity of the exchange.

NSE has broad-based, sectorial, thematic and strategy indices. Nifty 100 Low-Volatility 30, Nifty Alpha Low-Volatility 30, Nifty Alpha Quality Low-Volatility 30, Nifty Quality Low-Volatility 30, Nifty LowVolatility 50 are few of the strategy indices. These indices are based on the Low-Volatility (LV) effect. These indices have generated decent returns since their inception in 2003-2004 (see Figure 2).

Comparison of Nifty Low-Volatility 50 Index and Nifty 50 Index

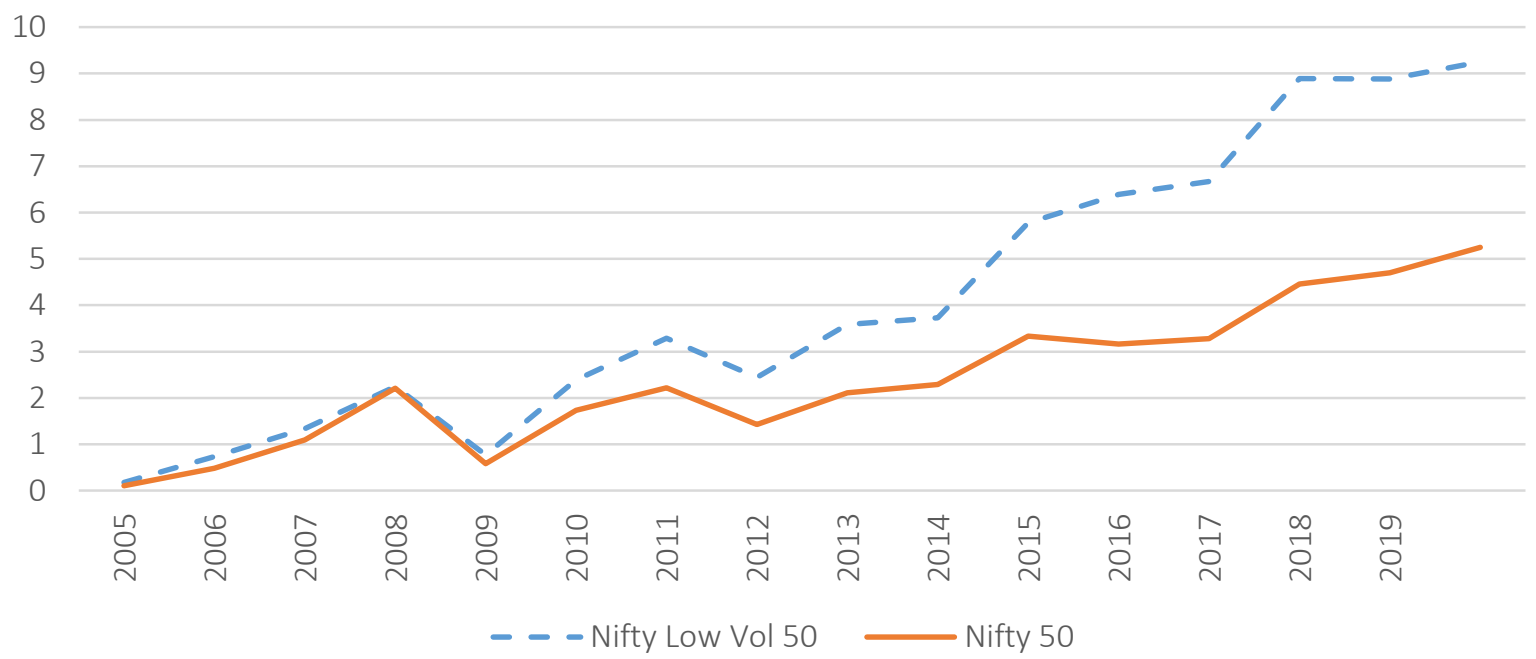

Figure 2. Comparison of returns from Nifty Low-Volatility 50 Index and Nifty 50 Index 
These pieces of evidences and discussions motivate us to study the Indian equity market to find the existence of the low-risk effect. For the study, the Indian equity market is represented by stocks listed on the National Stock Exchange (NSE). The period of the study is from January 1997 to September 2018. The study explores the presence of low-volatility effect and its robustness within and across various size buckets and also after controlling for established factors like size, value and momentum.

The objectives of the study are:

1. To find evidence for low-volatility effect in the Indian stock market.

2. To evaluate the characteristics and strength of the low-volatility effect in the Indian stock market.

3. To test the strength and robustness of the low-volatility effect within and across various size buckets (market capitalization) of large-cap, mid-cap and small-cap.

We study the returns of equally-weighted portfolios to meet the objectives mentioned above. We establish the following: (a) low-volatility (LV) effect delivers economically and statistically significant risk-adjusted returns, (b) LV often picks growth and winner stocks, (c) the long-short portfolios across the study deliver exceptionally high and statistically significant returns accompanied by negative beta, (d) the LV effect is not restricted to small or illiquid stocks, (e) LV delivers the highest risk-adjusted returns for the portfolio consisting of large-cap stocks, (f) irrespective of the method of portfolio construction, the LV effect exists and it also generates economically and statistically significant risk-adjusted returns.

The paper is organized as follows. Section 1 presents the literature review. Section 2 discusses data and methodology. Section 3 discusses the empirical findings of the study and final section concludes and defines the future scope of the study.

\section{LITERATURE REVIEW}

The Efficient Market Hypothesis is defied by implementing relatively simple investment strategies like value, size and momentum. These simple strategies are found to deliver significantly higher returns than benchmark indexes. Market efficiency is even flouted if any simple strategy delivers similar returns, but at a systematically low risk. One such strategy is the low-volatility effect. Low-volatility effect indicates that over a period, less risky investments deliver higher risk-adjusted returns than more risky investments. The effect was first documented by Haugen and Heins (1975). They found that systematic investment in a portfolio of low-volatility stocks over a period from 1926 to 1971 in the US equity market generate higher alpha than investment in a portfolio of high-volatility stocks. Even Black, Jensen, and Scholes (1972) observed that risk-return relationship was flatter than predicted by the Capital Asset Pricing Model (CAPM). It is obvious to expect higher returns from investment in high-risk asset, but within an asset class, low-volatility effect prevails. Black's proposal to Wells Fargo to commence an investment fund that systematically invests in low-risk stocks was rejected on the basis that the fund will not have any clientele (takers). Black's research was refuted for a long time. It was only after twenty years that Fama and French (1992) stated that after adjusting for size and value factors, the relation between return and beta was flat for the period 1963-1990. Since then, the lowrisk effect has been tested using various risk measures. Research has even created specific factors to exploit the low-risk effect.

Haugen and Baker (1991), Haugen and Baker (1996), Clarke et al. (2006), Blitz and Vliet (2007), Ang et al. (2006), Baker et al. (2011), Carvalho et al. (2012), and Frazzini and Pedersen (2014) offer evidence on the negative relation between risk and return. Blitz et al. (2013) find similar evidence for emerging markets. Joshipura and Peswani (2017) make similar observations for the Indian equity market.

However, there are studies that even refute these findings. Scherer (2011) argues that a large part of the excess return of minimum variance portfolio over the benchmark portfolio is explained 
by value effect. Shah (2011) argues that low-volatility effect is due to heavily investing in low-risk industries. Bali and Cakici (2008) argue that the low-risk effect is due to the presence of small and illiquid stocks with lottery-like payoffs. Further, to substantiate their argument, Bali et al. (2011) developed the lottery-like stocks payoff variable MAX. Though Martellini (2008) finds positive relationship between risk and return, their study has survivorship bias.

The explanations for the existence of low-volatility effect range from economic and market friction to behavioral biases. Black et al. (1972), Hong and Sraer (2012) and Frazzini and Pedersen (2014) attribute the returns to low-risk effect to borrowings restrictions. This makes investors demand high beta stocks to earn high returns. Blitz et al. (2013), Baker et al. (2012) show that the decentralized investing approach motivates fund managers to increase their investments in high-risk stocks with an expectation to earn high returns and in turn increase their personal compensation. It also makes the fund managers focus on out-performing in the bull market than performing in the bear market. Behavioral biases such as the preference for lotteries, over-confidence and representativeness motivate investors to demand high-risk stocks. This leads to an increase in price for high-risk stocks and reducing their subsequent returns.

In literature, studies on low-risk effect differ on the ground of the method of portfolio construction and the choice of risk measure. These studies measure risk in terms of total volatility, beta, or idiosyncratic volatility. Many have created factors based on the risk measures either to explain or refute the low-risk effect. In recent times, the empirical findings of low-risk effect are so consistent that they are accepted as truth.

\section{DATA AND METHODOLOGY}

\subsection{Data}

At the end of every month, starting in January 1997 and ending in September 2018, we identify all constituents of the National Stock Exchange of India (NSE) and take these as our universe for that particular month. The universe consists of approximately 900 stocks on average; the actual number varies between about 700 and 1,600 over time. The descriptive statistics of the universe is provided in Figures $3 \mathrm{~A}$ and $3 \mathrm{~B}$, which display number of stocks and total market capitalization of those stocks month-on-month.

Data on NSE constituents, market capitalization and stock price return are taken from Centre for Monitoring Indian Economy (CMIE) Prowess database. 91-day T-bill rate is taken from the Central Bank of India, the Reserve Bank of India (RBI) website. Fama-French (1992) and Carhart (1997) momentum factors for Indian equity market are taken from

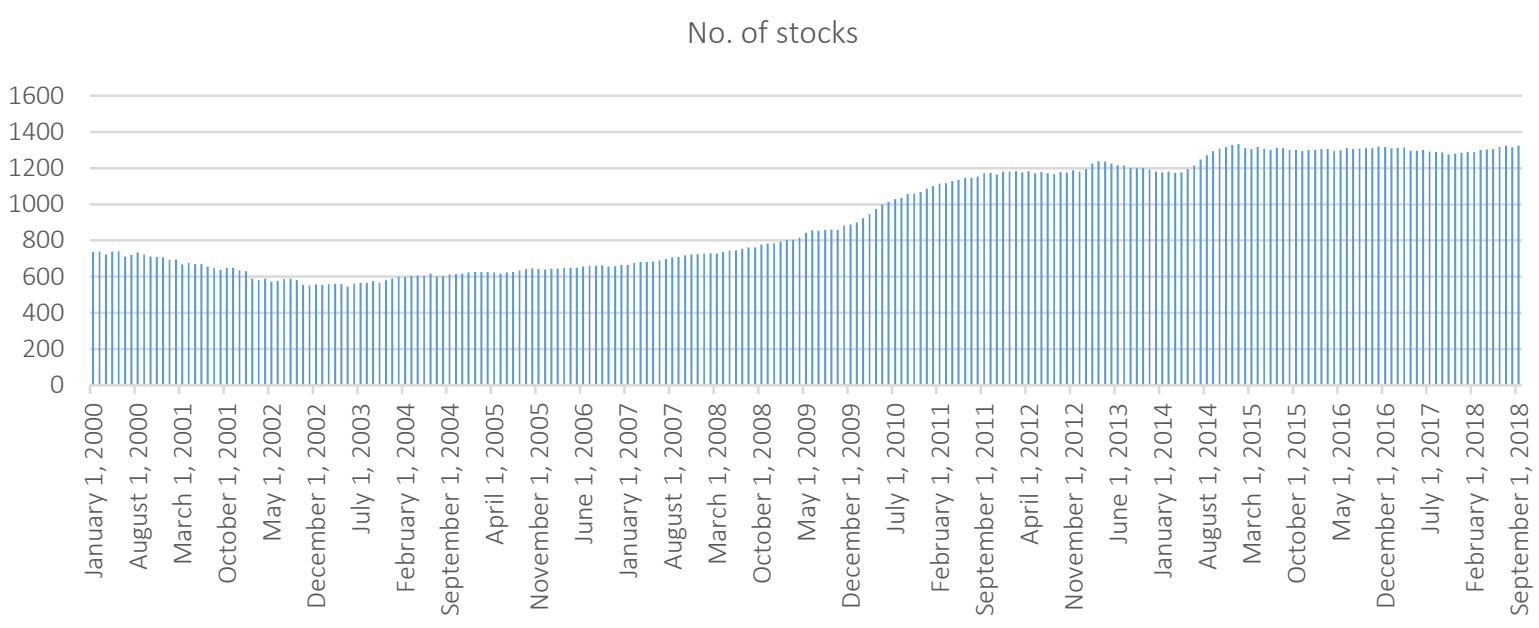

Figure 3A. Descriptive statistics - number of stocks 


\section{Market capitalization}

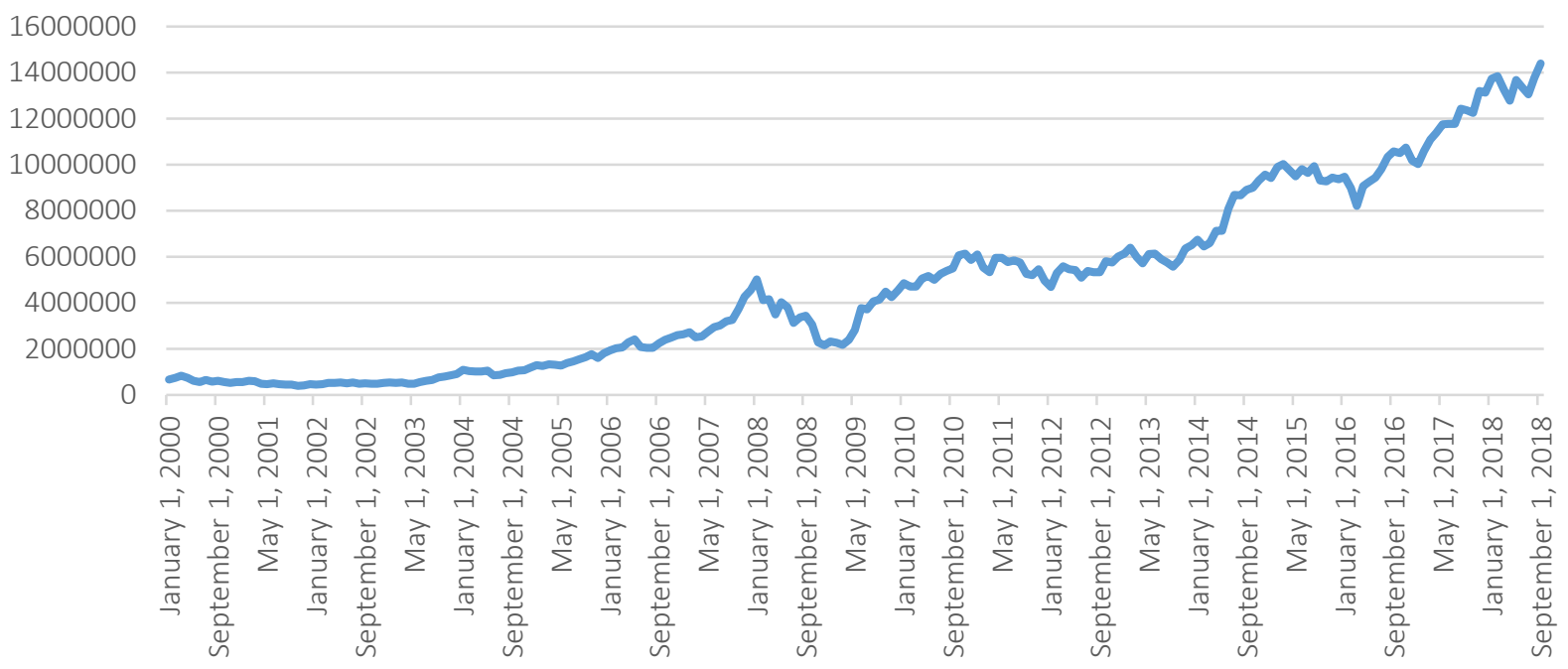

Figure 3B. Descriptive statistics - total market capitalization

the Indian Institute of Management Ahmedabad data library accessed in December 2018.

Returns are log-transformed in order to make them additive over time. The log-transformed excess returns are used throughout our analysis for all return calculations. Stocks with less than 12 months returns are weeded out. Also, we eliminate stocks that did not have a return in the month following the portfolio construction month $(t+1)$.

\subsection{Methodology}

At the end of each month $(t)$, we construct quintile portfolios by ranking stocks on the volatility of past 36 month's excess returns. We construct portfolios from January 2000 to September 2018 resulting in the creation of 225 portfolios (225 months of study). P1 consists of low-volatile stocks, while P5 consists of high-volatile stocks. The performance of these portfolios is measured in $t+1$. We calculated equally weighted returns of these portfolios. To make the study robust, we conducted the size and volatility study using three methods of portfolio construction.

\subsubsection{Method 1}

The first method creates portfolios using independent sort. The bivariate analysis uses double sorting of stocks. Stocks are sorted each month in ascending order on size to form quintile portfolios and then within each size quintile, they are re-sorted in ascending order of the stock's historical volatility. As a result, every month, we create 25 portfolios $(5 \times 5)$. P1 portfolio consists of small-size stocks, while P5 portfolio consists of large-size stocks. Bucket 'A' consists of low-volatility stocks and bucket ' $\mathrm{E}$ ' consists of high-volatility stocks within a particular size quintile. The bivariate analysis is a robust non-parametric technique to evaluate whether the low-volatility effect is a separate effect or the one which is present only in small-size stocks (Bali, Cakici, \& Whitelaw, 2011).

\subsubsection{Method 2}

The second method creates portfolios using dependent sort. Each month, stocks are sorted on size, from small-cap to large-cap, to create quintile buckets and within each size quintile, stocks are re-sorted on historical volatility. P1 to P5 are size quintiles with an equal number of stocks in each quintile. Within each quintile, 'A' to ' $E$ ' are the volatility quintiles. ' $A$ ' has stocks with the lowest volatility and ' $E$ ' bears stocks with the highest volatility. Then, every month, P1A, P2A, $\mathrm{P} 3 \mathrm{~A}, \mathrm{P} 4 \mathrm{~A}$ and $\mathrm{P} 5 \mathrm{~A}$ are combined to create the low-volatility (LV) quintile. The same is repeated for all other quintiles. Thus, P1E, P2E, P3E, $\mathrm{P} 4 \mathrm{E}$ and $\mathrm{P} 5 \mathrm{E}$ are combined to form the portfolio 
of stocks with the high-volatility (HV) quintile. This helps to study the low-volatility effect controlling for size.

\subsubsection{Method 3}

The third method uses the Securities Exchange Board of India (SEBI) guidelines to segregate Indian stocks into large-cap, mid-cap and smallcap. SEBI has defined large-cap stocks as top 100 by market capitalization. Next 150 belong to the mid-cap size bucket, while the rest of the stocks belong to the small-cap size bucket. Each month, stocks are divided into these three groups. At the end of each month, we create quintile portfolios within each size bucket.

For all the methods mentioned above, portfolios are rebalanced with a monthly frequency throughout the analysis. For the resulting time series, we calculate the equally weighted excess portfolio return, standard deviation, Sharpe ratio, ex-post beta, CAPM style alpha and its $t$-value in the month $t+1$.

We evaluate the performance of the portfolio returns using single factor CAPM style alpha using equation 1, Fama-French 3 factor alpha and FamaFrench-Carhart 4 factor alpha using the equations (2) and (3) respectively. We use the equally weighted excess stocks returns of all the stocks listed on NSE as a proxy for the market.

$$
R_{p, t}-R_{f, t}=\alpha_{p}+\beta_{p, m}\left(R_{m, t}-R_{f, t}\right)+\varepsilon_{p, t}
$$

where $R_{p, t}, R_{f, t}, R_{m, t}$ and $\varepsilon_{p, t}$ are the return on the portfolio $p$, risk-free rate, the return of the market portfolio and idiosyncratic volatility, respectively, in time $t$. The alpha of the portfolio is represented by $\alpha_{p}$. The Fama-French 3 factor and Fama-French-Carhart 4 factor analysis are conducted by adding SMB, HML and WML factors to the above equation 1 .

$$
\begin{aligned}
& R_{p, t}-R_{f, t}=\alpha_{p}+\beta_{p, m}\left(R_{m, t}-R_{f, t}\right)+ \\
& +\beta_{p} S M B \cdot R S M B+\beta_{p} H M L \cdot R H M L+\varepsilon_{p, t},
\end{aligned}
$$

$$
\begin{aligned}
& R_{p, t}-R_{f, t}=\alpha_{p}+\beta_{p, m}\left(R_{m, t}-R_{f, t}\right)+ \\
& +\beta_{p} S M B \cdot R S M B+\beta_{p} H M L \cdot R H M L+ \\
& +\beta_{p} W M L \cdot R W M L+\varepsilon_{p, t}
\end{aligned}
$$

where $R S M B, R H M L$ and $R W M L$ represent the return on size, value and momentum factors, respectively, and $\beta_{p} S M B, \beta_{p} H M L$ and $\beta_{p} W M L$ represent betas of the portfolio of size, value and momentum respectively.

\section{EMPIRICAL RESULTS}

We discuss the results of our study in this section.

We report in Table 1 the excess annualized returns of the equally weighted portfolios created by ranking stocks on their historical volatility, the standard deviation of these quintile portfolios, annualized Sharpe ratio, ex-post beta, CAPM alpha with its statistical significance. In this univariate analysis, we observe that the returns monotonically decrease from the portfolio

\begin{tabular}{|c|c|c|c|c|c|c|c|}
\hline Key metrics & P1 (LV) & P2 & P3 & P4 & P5 (HV) & P1-P5 (LV-HV) & EWI \\
\hline Excess returns & $5.15 \%$ & $3.84 \%$ & $-1.50 \%$ & $-7.06 \%$ & $-23.32 \%$ & $28.47 \%$ & $1.65 \%$ \\
\hline Standard deviation & $23.35 \%$ & $30.56 \%$ & $34.86 \%$ & $39.50 \%$ & $46.15 \%$ & $27.47 \%$ & $33.66 \%$ \\
\hline Sharpe ratio & 0.22 & 0.13 & -0.04 & -0.18 & -0.51 & 1.04 & 0.05 \\
\hline Ex-post beta & 0.66 & 0.88 & 1.01 & 1.15 & 1.31 & -0.65 & - \\
\hline CAPM alpha & $8.14 \%$ & $7.83 \%$ & $3.09 \%$ & $-1.86 \%$ & $-17.39 \%$ & $25.53 \%$ & - \\
\hline$t$-value & 5.79 & 6.41 & 2.94 & -1.77 & -6.64 & 6.81 & - \\
\hline
\end{tabular}
of low-volatility stocks (P1) to the portfolio of high-volatility stocks (P5). The standard deviation and ex-post beta of these returns increase from P1 to P5. The Sharpe ratio of P1 is greater

Table 1. Risk and return of volatility ranked portfolios

Note: The table reports equally weighted excess annualized returns, annualized standard deviation, Sharpe ratio, ex-post beta and CAPM style alpha with its $t$-value. We created quintile portfolios by ranking stocks on their historical volatility of returns. P1 consists of low-volatility stocks, while P5 consists of high-volatility stocks. Returns, standard deviation and alphas are in percent. 
Table 2. CAPM style alpha, three-factor alpha and four-factor alpha of volatility ranked portfolios

\begin{tabular}{|c|c|c|c|c|c|c|}
\hline Key metrics & P1 (LV) & P2 & P3 & P4 & P5 (HV) & P1-P5 (LV-HV) \\
\hline CAPM style alpha & $8.14 \%$ & $7.83 \%$ & $3.09 \%$ & $-1.86 \%$ & $-17.39 \%$ & $25.53 \%$ \\
\hline$t$-value & 5.79 & 6.41 & 2.94 & -1.77 & -6.64 & 6.81 \\
\hline 3F alpha & $9.37 \%$ & $8.61 \%$ & $3.23 \%$ & $-2.84 \%$ & $-18.58 \%$ & $27.95 \%$ \\
\hline$t$-value & 7.23 & 7.41 & 3.06 & -2.88 & -7.36 & 7.92 \\
\hline $4 \mathrm{~F}$ alpha & $8.84 \%$ & $8.49 \%$ & $3.23 \%$ & $-2.82 \%$ & $-17.93 \%$ & $26.77 \%$ \\
\hline$t$-value & 6.85 & 7.22 & 3.02 & -2.82 & -7.06 & 7.57 \\
\hline
\end{tabular}

Note: The table reports CAPM alpha, three-factor alpha and four-factor alpha with their t-value of equally weighted portfolios formed by sorting on historical volatility of stock returns. Alphas are in percent. $5 \%$ significance is indicated in bold.

than that of the benchmark index. It is negative for P5. The CAPM alpha is economically and statistically significant for all quintiles barring P4. The same stands true for all the long-short portfolio where we go long P1 and short P5.

Table 2 reports the CAPM style alpha, FamaFrench three-factor alpha (3F) and FamaFrench-Carhart four-factor alpha (4F) with their statistical significance. The alphas are statistically significant for all quintile portfolios. Moreover, P1 delivers reasonable high alpha even after controlling for known factors like size, value and momentum. These results clearly defy the efficient market theory.

We also observe in Table 3 that $4 \mathrm{~F}$ of $\mathrm{P} 1$ has negative significant loading on size, as well as value factor, whereas significant positive loading on momentum factor. So LV portfolio comprises largecap, growth and winner stocks. Therefore, neither size nor value premium can explain the economic and statistically significant alpha associated with the LV portfolio. Only a part of the CAPM alpha can be explained by the momentum factor.
Table 3. Three-factor and four-factor regression coefficients of volatility extreme portfolios

\begin{tabular}{l|c:c|c:c}
\hline \multirow{2}{*}{$\begin{array}{c}\text { Factor } \\
\text { loading }\end{array}$} & \multicolumn{2}{|c|}{ P1 } & \multicolumn{2}{c}{ P5 } \\
\cline { 2 - 5 } & $\mathbf{3 F}$ & $\mathbf{4 F}$ & $\mathbf{3 F}$ & $\mathbf{4 F}$ \\
\hline $\mathrm{EWI}$ & 0.723 & 0.737 & 1.228 & 1.211 \\
\hline$t$-value & 50.78 & 49.49 & 44.30 & 41.34 \\
\hline $\mathrm{SMB}$ & -0.143 & -0.148 & 0.244 & 0.249 \\
\hline$t$-value & -5.56 & -5.81 & 4.85 & 4.97 \\
\hdashline $\mathrm{HML}$ & -0.078 & -0.081 & 0.055 & 0.059 \\
\hdashline$t$-value & -4.03 & -4.26 & 1.47 & 1.58 \\
\hline WML & - & 0.044 & - & -0.054 \\
\hline$t$-value & - & 2.78 & - & -1.71 \\
\hline
\end{tabular}

Note: The table reports three-factor (Fama-French) and fourfactor (Fama-French-Carhart) style regression coefficient analysis of extreme portfolios.

In Table 4, we report the results of our first method to study the low-volatility effect controlling the size factor. The method creates $5 \times 5$ quintile portfolios of stocks first sorted on size and within each size quintile, re-sorted on historical volatility to create quintile portfolios. This bivariate analysis reveals that portfolios of low-volatility stocks across size quintiles deliver positive excess returns and vice versa.

Table 4. Excess returns of independent sort portfolios on size and volatility

\begin{tabular}{|c|c|c|c|c|c|c|c|c|}
\hline \multirow{2}{*}{\multicolumn{2}{|c|}{$\begin{array}{c}\text { Size } \\
\text { P1 (SC) }\end{array}$}} & \multicolumn{5}{|c|}{ Small-cap to large-cap } & \multirow{2}{*}{ P1-P5 } & \multirow{2}{*}{ EWI } \\
\hline & & P2 & P3 & P4 & P5 (LC) & & & \\
\hline \multirow{5}{*}{ Low to high-volatility } & $A(L V)$ & $6.51 \%$ & $8.35 \%$ & $3.90 \%$ & $5.72 \%$ & $5.93 \%$ & $0.57 \%$ & $1.65 \%$ \\
\hline & B & $0.84 \%$ & $0.52 \%$ & $3.81 \%$ & $1.89 \%$ & $3.72 \%$ & $-2.87 \%$ & - \\
\hline & c & $-6.77 \%$ & $-2.51 \%$ & $-1.12 \%$ & $3.66 \%$ & $1.37 \%$ & $-8.13 \%$ & - \\
\hline & $\mathrm{D}$ & $-13.77 \%$ & $-11.05 \%$ & $-5.27 \%$ & $-3.60 \%$ & $-3.75 \%$ & $-10.02 \%$ & - \\
\hline & $E(H V)$ & $-22.33 \%$ & $-31.51 \%$ & $-21.77 \%$ & $-15.61 \%$ & $-19.36 \%$ & $-2.98 \%$ & - \\
\hline \multicolumn{2}{|l|}{$A-E(L V-H V)$} & $28.84 \%$ & $39.87 \%$ & $25.67 \%$ & $21.33 \%$ & $25.29 \%$ & - & - \\
\hline
\end{tabular}

Note: The $5 \times 5$ quintile portfolios are independently sorted first on size (market capitalization) and within each quintile resorted on volatility in ascending order. We calculate equally weighted returns of each portfolio. Similarly, we created longshort portfolios, which go long on low-volatility stocks and short on high-volatility stocks. We calculate equally weighted returns on these portfolios. Returns are annualized percent. 
Table 5. Ex-post beta ratio of quintile portfolios independently sorted on size and volatility

\begin{tabular}{|c|c|c|c|c|c|c|c|}
\hline \multirow{2}{*}{\multicolumn{2}{|c|}{ Size }} & \multicolumn{5}{|c|}{ Small-cap to large-cap } & \multirow{2}{*}{ P1-P5 } \\
\hline & & P1 (SC) & $\mathbf{P 2}$ & P3 & P4 & P5 (LC) & \\
\hline \multirow{5}{*}{ Low to high-volatility } & $A(L V)$ & 0.994 & 0.866 & 0.755 & 0.650 & 0.468 & 0.53 \\
\hline & B & 1.166 & 1.005 & 0.923 & 0.797 & 0.636 & 0.53 \\
\hline & C & 1.193 & 1.132 & 1.043 & 0.900 & 0.763 & 0.43 \\
\hline & $D$ & 1.251 & 1.200 & 1.130 & 1.031 & 0.866 & 0.39 \\
\hline & $E(H V)$ & 1.336 & 1.305 & 1.229 & 1.221 & 1.135 & 0.20 \\
\hline \multicolumn{2}{|l|}{$\mathrm{A}-\mathrm{E}(\mathrm{LV}-\mathrm{HV})$} & -0.34 & -0.44 & -0.47 & -0.57 & -0.67 & - \\
\hline
\end{tabular}

Note: The $5 \times 5$ quintile portfolios are independently sorted first on size and within each quintile re-sorted on historical volatility. We regress each portfolio's monthly excess return on the market excess return to find a full-period ex-post beta.

We observe that the ex-post beta of P5A (largecap stocks) portfolio is less than P1A (small-cap stocks) portfolio (see Table 5).

Also, the long-short portfolios within each size bucket (A-E) deliver exceptionally high Sharpe ratio (see Table 6) as compared to the Sharpe ratio of the benchmark index. Though the returns of the portfolio comprising of large-cap low-volatility stocks $(5.93 \%)$ are lower than the returns of the portfolio comprising of small-cap low-volatility stocks (6.51\%), its Sharpe ratio is higher (0.319) be- cause of less riskiness of large-cap stocks as compared to small-cap stocks.

Further, we analyze the CAPM style alpha, 3F and $4 \mathrm{~F}$ alphas with their $t$-values of all these 25 portfolios created every month (see Tables 7, 8 and 9). Again, we observe that all the portfolios of low-volatility stocks within all size buckets earn economically and statistically significant alphas even after controlling for known factors like size, value and momentum. The alpha is superbly high for longshort portfolios within all size buckets (LV-HV).

Table 6. Sharpe ratio of quintile portfolios independently sorted on size and volatility

\begin{tabular}{|c|c|c|c|c|c|c|c|c|}
\hline \multicolumn{2}{|l|}{ Size } & \multicolumn{6}{|c|}{ Small-cap to large-cap } & \multirow[t]{3}{*}{ EWI } \\
\hline \multirow{5}{*}{ Low to high-volatility } & $A(L V)$ & 0.178 & 0.271 & 0.144 & 0.243 & 0.319 & 0.022 & \\
\hline & B & 0.020 & 0.015 & 0.116 & 0.066 & 0.150 & -0.092 & \\
\hline & C & -0.150 & -0.062 & -0.031 & 0.113 & 0.047 & -0.255 & \multirow[t]{3}{*}{0.049} \\
\hline & D & -0.292 & -0.261 & -0.133 & -0.098 & -0.115 & -0.303 & \\
\hline & $\mathrm{E}(\mathrm{HV})$ & -0.433 & -0.674 & -0.496 & -0.350 & -0.434 & -0.077 & \\
\hline \multicolumn{2}{|l|}{ A-E (LV-HV) } & 1.157 & 1.749 & 1.080 & 0.807 & 0.807 & - & - \\
\hline
\end{tabular}

Note: The $5 \times 5$ quintile portfolios are independently sorted first on size and within each quintile re-sorted on historical volatility. Annualized Sharpe ratio are reported above.

Table 7. CAPM style alpha of quintile portfolios independently sorted on size and volatility

\begin{tabular}{|c|c|c|c|c|c|c|c|}
\hline \multirow{2}{*}{\multicolumn{2}{|c|}{ Size }} & \multicolumn{5}{|c|}{ Small-cap to large-cap } & \multirow{2}{*}{ P1-P5 } \\
\hline & & P1 (SC) & $\mathbf{P 2}$ & P3 & P4 & P5 (LC) & \\
\hline \multirow{12}{*}{ Low to high-volatility } & \multirow{2}{*}{$A(L V)$} & $11.02 \%$ & $12.28 \%$ & $7.32 \%$ & $8.67 \%$ & $8.06 \%$ & $2.96 \%$ \\
\hline & & 3.554 & 6.188 & 3.762 & 4.850 & 3.684 & 0.689 \\
\hline & \multirow{2}{*}{ B } & $6.14 \%$ & $5.08 \%$ & $7.99 \%$ & $5.50 \%$ & $6.61 \%$ & $-0.47 \%$ \\
\hline & & 1.646 & 2.393 & 3.970 & 2.819 & 2.385 & -0.080 \\
\hline & \multirow{2}{*}{ C } & $-1.35 \%$ & $2.63 \%$ & $3.61 \%$ & $7.74 \%$ & $4.83 \%$ & $-6.18 \%$ \\
\hline & & -0.302 & 1.068 & 1.842 & 3.266 & 1.704 & -0.943 \\
\hline & \multirow{2}{*}{$\mathrm{D}$} & $-8.09 \%$ & $-5.61 \%$ & $-0.14 \%$ & $1.08 \%$ & $0.18 \%$ & $-8.27 \%$ \\
\hline & & -1.773 & -2.416 & -0.073 & 0.437 & 0.057 & -1.179 \\
\hline & \multirow{2}{*}{$E(H V)$} & $-16.27 \%$ & $-25.59 \%$ & $-16.19 \%$ & $-10.07 \%$ & $-14.21 \%$ & $-2.07 \%$ \\
\hline & & -2.938 & -8.023 & -5.520 & -2.781 & -2.789 & -0.234 \\
\hline & \multirow{2}{*}{$A-E(L V-H V)$} & $27.29 \%$ & $37.88 \%$ & $23.51 \%$ & $18.74 \%$ & $22.26 \%$ & - \\
\hline & & 5.353 & 9.538 & 5.849 & 4.548 & 4.477 & - \\
\hline
\end{tabular}

Note: The quintile portfolios are independently sorted first on size and within each quintile re-sorted on volatility. We regress each portfolio's monthly excess return on the market excess return. The table reports CAPM alpha of these portfolios. Alpha are in annualized percent. $5 \%$ significance is indicated in bold. 
Table 8. Three-factor alpha of quintile portfolios independently sorted on size and volatility

\begin{tabular}{|c|c|c|c|c|c|c|c|}
\hline \multirow{2}{*}{\multicolumn{2}{|c|}{ Size }} & \multicolumn{5}{|c|}{ Small-cap to large-cap } & \multirow{3}{*}{$\begin{array}{c}\text { P1-P5 } \\
-3.21 \%\end{array}$} \\
\hline & & \multirow{2}{*}{$\begin{array}{c}\mathrm{P1} \text { (SC) } \\
7.31 \%\end{array}$} & \multirow{2}{*}{$\begin{array}{c}\text { P2 } \\
10.92 \%\end{array}$} & \multirow{2}{*}{$\begin{array}{c}\text { P3 } \\
7.26 \%\end{array}$} & \multirow{2}{*}{$\begin{array}{c}\text { P4 } \\
9.67 \%\end{array}$} & \multirow{2}{*}{$\begin{array}{l}\text { P5 (LC) } \\
10.51 \%\end{array}$} & \\
\hline \multirow{12}{*}{ Low to high-volatility } & \multirow{2}{*}{$A(L V)$} & & & & & & \\
\hline & & 2.667 & 5.615 & 3.657 & 5.437 & 5.837 & -0.967 \\
\hline & \multirow{2}{*}{ B } & $1.05 \%$ & $3.31 \%$ & $7.84 \%$ & $7.32 \%$ & $10.56 \%$ & $-9.51 \%$ \\
\hline & & 0.344 & 1.622 & 3.818 & 3.986 & 5.164 & -2.245 \\
\hline & \multirow{2}{*}{ C } & $-7.19 \%$ & $0.33 \%$ & $3.41 \%$ & $9.36 \%$ & $8.87 \%$ & $-16.06 \%$ \\
\hline & & -1.866 & 0.143 & 1.711 & 4.101 & 4.516 & -3.264 \\
\hline & \multirow{2}{*}{ D } & $-14.55 \%$ & $-7.62 \%$ & $-0.55 \%$ & $3.56 \%$ & $4.94 \%$ & $-19.49 \%$ \\
\hline & & -3.830 & -3.477 & -0.273 & 1.577 & 2.266 & -3.798 \\
\hline & \multirow{2}{*}{$E(H V)$} & $-22.46 \%$ & $-26.08 \%$ & $-14.17 \%$ & $-5.46 \%$ & $-6.87 \%$ & $-15.58 \%$ \\
\hline & & -4.458 & -8.375 & -4.960 & -1.683 & -1.619 & -2.198 \\
\hline & \multirow{2}{*}{$A-E(L V-H V)$} & $29.76 \%$ & $37.00 \%$ & $21.43 \%$ & $15.13 \%$ & $17.39 \%$ & - \\
\hline & & 5.824 & 9.292 & 5.339 & 3.804 & 3.678 & - \\
\hline
\end{tabular}

Note: The 25 quintile portfolios are independently sorted first on size and within each quintile re-sorted on volatility. We regress each portfolio's monthly excess return on the market excess return, size and value factors. The table reports threefactor alpha of these $5 \times 5$ and long-short portfolios. Alphas are annualized percent. $5 \%$ significance is indicated in bold.

Table 9. Four-factor alpha of quintile portfolios independently sorted on size and volatility

\begin{tabular}{|c|c|c|c|c|c|c|c|}
\hline \multirow{2}{*}{ Size } & & \multicolumn{5}{|c|}{ Small-cap to large-cap } & \multirow{2}{*}{ P1-P5 } \\
\hline & & P1 (SC) & P2 & P3 & P4 & P5 (LC) & \\
\hline \multirow{12}{*}{ Low to high-volatility } & \multirow{2}{*}{$A(L V)$} & $7.12 \%$ & $10.59 \%$ & $6.89 \%$ & $9.86 \%$ & $9.30 \%$ & $-2.17 \%$ \\
\hline & & 2.566 & 5.387 & 3.438 & 5.475 & 5.343 & -0.653 \\
\hline & \multirow{2}{*}{ B } & $1.16 \%$ & $3.54 \%$ & $8.16 \%$ & $7.37 \%$ & $9.56 \%$ & $-8.40 \%$ \\
\hline & & 0.373 & 1.715 & 3.930 & 3.961 & 4.726 & -1.971 \\
\hline & \multirow{2}{*}{ C } & $-7.45 \%$ & $-0.15 \%$ & $3.29 \%$ & $9.46 \%$ & $7.82 \%$ & $-15.28 \%$ \\
\hline & & -1.910 & -0.065 & 1.627 & 4.088 & 4.046 & -3.072 \\
\hline & \multirow{2}{*}{ D } & $-14.11 \%$ & $-7.36 \%$ & $-0.16 \%$ & $4.41 \%$ & $4.61 \%$ & $-18.72 \%$ \\
\hline & & -3.670 & -3.321 & -0.078 & 1.950 & 2.090 & -3.606 \\
\hline & \multirow{2}{*}{$E(H V)$} & $-22.23 \%$ & $-25.31 \%$ & $-14.02 \%$ & $-4.45 \%$ & $-6.66 \%$ & $-15.57 \%$ \\
\hline & & -4.356 & -8.070 & -4.842 & -1.367 & -1.548 & -2.167 \\
\hline & \multirow{2}{*}{$A-E(L V-H V)$} & $29.36 \%$ & $35.90 \%$ & $20.91 \%$ & $14.31 \%$ & $15.95 \%$ & (-) \\
\hline & & 5.672 & 8.965 & 5.148 & 3.565 & 3.361 & - \\
\hline
\end{tabular}

Note: The portfolios are created by independently sorting first on size and within each quintile re-sorting on volatility. We regress each portfolio's monthly excess return on the market excess return, size, value and momentum factors. The table reports fourfactor alpha of these $5 \times 5$ and long-short portfolios. Alphas are annualized percent. 5\% significance is indicated in bold.

The $3 \mathrm{~F}$ and $4 \mathrm{~F}$ factor coefficient analysis (Tables 10 and 11) rightly suggest that all $\mathrm{P} 1$ portfolios (P1A to P1E) consist of small-cap stocks and all the P5 portfolios (P5A to P5E) consists of large-cap stocks. The study also reveals that the portfolio of large-cap stocks consists of growth stocks, while the portfolio of small-cap stocks consists of value stocks. Moreover, the results reveal that portfolios consisting of low-volatility stocks pick up winner stocks across size buckets.

Table 10. Regression coefficient analysis of three-factor (Fama-French) alpha of portfolios independently sorted on size and volatility with their corresponding $t$-value

\begin{tabular}{|c|c|c|c|c|c|c|c|c|c|c|}
\hline 3F Loading & P1A & P1B & P1C & P1D & P1E & P5A & P5B & P5C & P5D & P5E \\
\hline EWI & 0.825 & 0.926 & 0.929 & 0.963 & 1.062 & 0.601 & 0.839 & 0.980 & 1.109 & 1.455 \\
\hline$t$-value & 27.416 & 27.538 & 21.964 & 23.091 & 19.193 & 30.398 & 37.375 & 45.418 & 46.307 & 31.206 \\
\hline SMB & 0.293 & 0.453 & 0.445 & 0.474 & 0.443 & -0.323 & -0.447 & -0.513 & -0.530 & -0.495 \\
\hline$t$-value & 5.378 & 7.448 & 5.812 & 6.279 & 4.424 & -9.027 & -11.001 & -13.150 & -12.237 & -5.868 \\
\hline $\mathrm{HML}$ & 0.258 & 0.344 & 0.409 & 0.456 & 0.439 & -0.147 & -0.250 & -0.245 & -0.303 & -0.526 \\
\hline$t$-value & 6.357 & 7.577 & 7.157 & 8.091 & 5.874 & -5.504 & -8.251 & -8.414 & -9.364 & -8.358 \\
\hline
\end{tabular}

Note: The table reports the three-factor (Fama-French) regression coefficients of extreme portfolios created through independent sort on size and historical volatility with their corresponding $t$-value. $5 \%$ significance is indicated in bold. 
Table 11. Regression coefficient analysis of three-factor (Fama-French) alpha of portfolios independently sorted on size and volatility with their corresponding $t$-value

\begin{tabular}{|c|c|c|c|c|c|c|c|c|c|c|}
\hline 4F Loading & P1A & P1B & P1C & P1D & P1E & P5A & P5B & P5C & P5D & P5E \\
\hline EWI & 0.830 & 0.923 & 0.936 & 0.952 & 1.056 & 0.633 & 0.866 & 1.007 & 1.118 & 1.449 \\
\hline$t$-value & 25.930 & 25.813 & 20.809 & 21.474 & 17.944 & 31.556 & 37.137 & 45.193 & 43.967 & 29.226 \\
\hline SMB & 0.291 & 0.454 & 0.443 & 0.478 & 0.445 & -0.333 & -0.455 & -0.522 & -0.533 & -0.493 \\
\hline$t$-value & 5.330 & 7.431 & 5.761 & 6.309 & 4.425 & -9.726 & -11.440 & -13.716 & -12.278 & -5.824 \\
\hline $\mathrm{HML}$ & 0.257 & 0.345 & 0.407 & 0.459 & 0.440 & -0.155 & -0.257 & -0.252 & -0.305 & -0.525 \\
\hline$t$-value & 6.304 & 7.559 & 7.100 & 8.117 & 5.868 & -6.052 & -8.637 & -8.863 & -9.410 & -8.302 \\
\hline WML & 0.015 & -0.008 & 0.022 & -0.037 & -0.019 & 0.101 & 0.084 & 0.087 & 0.028 & -0.018 \\
\hline$t$-value & 0.445 & -0.220 & 0.460 & -0.774 & -0.295 & 4.709 & 3.348 & 3.655 & 1.015 & -0.337 \\
\hline
\end{tabular}

Note: The table reports the four-factor regression coefficients of extreme portfolios created through independent sort on size and historical volatility with their corresponding t-value. $5 \%$ significance is indicated in bold.

Tables 12-14 report the result of the second method adopted to create the size and volatility portfolios. Table 12 displays the risk and return of these dependent sort portfolios created by ranking on volatility while controlling for size. The trend of their return is like the one observed in Table 2. CAPM alpha delivered by 'A' portfolio is $9.48 \%$ and decreases as volatility increases. It is also statistically significant.

The $3 \mathrm{~F}$ and $4 \mathrm{~F}$ alphas are also phenomenally high and also statistically significant (Table 13). This also proves that the low-volatility effect is not an overlap of any other established factor.

The regression coefficients of size factor in $3 \mathrm{~F}$ and $4 \mathrm{~F}$ analysis (Table 14) are rightly insignificant as the method of construction itself controls for size. The strategy re-confirms that the portfolio of low-volatility stocks picks winner stocks, but we also observe a contradiction to our earlier observation, where it picks growth stocks. Here, portfolio 'E' picks growth stocks instead. To explain this, Joshipura and Peswani (2018) observe that

Table 12. Risk and return of dependent portfolios sorted on volatility and controlled for size

\begin{tabular}{|c|c|c|c|c|c|c|}
\hline Key metrics & A & B & C & D & $\mathbf{E}$ & A-E \\
\hline Excess returns & $6.09 \%$ & $2.17 \%$ & $-1.06 \%$ & $-7.47 \%$ & $-22.05 \%$ & $28.14 \%$ \\
\hline Standard deviation & $26.03 \%$ & $31.26 \%$ & $34.68 \%$ & $37.69 \%$ & $43.65 \%$ & $21.90 \%$ \\
\hline Sharpe ratio & 0.23 & 0.07 & -0.03 & -0.20 & -0.51 & 1.29 \\
\hline Ex-post beta & 0.75 & 0.91 & 1.01 & 1.10 & 1.24 & -0.50 \\
\hline CAPM alpha & $9.48 \%$ & $6.28 \%$ & $3.51 \%$ & $-2.50 \%$ & $-16.41 \%$ & $25.88 \%$ \\
\hline$t$-value & 8.14 & 6.54 & 3.63 & -2.81 & -7.37 & 8.12 \\
\hline
\end{tabular}

Note: The table reports annualized equally weighted excess portfolio returns, standard deviation, Sharpe ratio, ex-post beta and CAPM style alpha with their $t$-value. Each quintile portfolio is created by sorting on volatility after controlling for size. We create dependent size-volatility portfolios. " $\mathrm{A}$ " are portfolios with low-volatility and " $\mathrm{E}$ " are portfolios of stocks with highest volatility controlled for size.

Table 13. CAPM style alpha, three-factor and four-factor alphas of volatility ranked portfolios controlled for size

\begin{tabular}{|c|c|c|c|c|c|c|}
\hline Key metrics & A & B & C & D & $\mathbf{E}$ & A-E \\
\hline CAPM alpha & $9.48 \%$ & $6.28 \%$ & $3.51 \%$ & $-2.50 \%$ & $-16.41 \%$ & $25.88 \%$ \\
\hline$t$-value & 8.14 & 6.54 & 3.63 & -2.81 & -7.37 & 8.12 \\
\hline 3F alpha & $9.14 \%$ & $6.03 \%$ & $2.97 \%$ & $-2.82 \%$ & $-14.93 \%$ & $24.07 \%$ \\
\hline$t$-value & 7.73 & 6.18 & 3.10 & -3.15 & -6.80 & 7.58 \\
\hline 4F alpha & $8.75 \%$ & $5.97 \%$ & $2.61 \%$ & $-2.50 \%$ & $-14.46 \%$ & $23.21 \%$ \\
\hline$t$-value & 7.38 & 6.03 & 2.72 & -2.79 & -6.53 & 7.27 \\
\hline
\end{tabular}

Note: The table reports one-factor, three-factor and four-factor alphas along with their t-value for portfolios created by ranking on historical volatility controlling for size. Alphas are annualized percent. $5 \%$ significance is indicated in bold. 
Table 14. Three-factor and four-factor regression coefficients of dependent portfolios ranked on volatility and controlled for size

\begin{tabular}{|c|c|c|c|c|}
\hline \multirow{2}{*}{ Factor loadings } & \multicolumn{2}{|c|}{$A(L V)$} & \multicolumn{2}{|c|}{$E(H V)$} \\
\hline & $3 F$ & $4 \mathrm{~F}$ & $3 F$ & $4 \mathrm{~F}$ \\
\hline EWI & 0.734 & 0.744 & 1.287 & 1.275 \\
\hline$t$-value & 56.55 & 54.45 & 53.42 & 49.96 \\
\hline SMB & 0.008 & 0.004 & 0.026 & 0.030 \\
\hline$t$-value & 0.33 & 0.19 & 0.60 & 0.69 \\
\hline $\mathrm{HML}$ & 0.027 & 0.025 & -0.129 & -0.126 \\
\hline$t$-value & 1.55 & 1.42 & -3.97 & -3.88 \\
\hline WML & - & 0.032 & - & -0.039 \\
\hline$t$-value & - & 2.18 & - & -1.44 \\
\hline
\end{tabular}

Note: The table reports three-factor (Fama-French) and four-factor (Fama-French-Carhart) style regression coefficient analysis of dependent portfolios ranked on volatility and controlled for size.

low-volatility effect enhances the returns from low-volatility stocks deliver comparatively highthe portfolio of value, as well as growth stocks. er risk-adjusted returns than investing in midSo though the dependent sort method of portfolio creation chose value stocks in the portfolio of low-volatility stocks (results are insignificant), it delivers exceptionally high alphas.

The results established in Tables 15, 16 and 17 are of the third method of portfolio formation adopted to study the robustness of the low-volatility effect within and across various size buckets. We observe that investing in large-cap cap or small-cap low-volatility stocks (see Table 15). Even the Sharpe ratio is the highest for the portfolio of large-cap low-volatility stocks, but lower than the long-short portfolio (P1-P5). The ex-post beta of large-cap P1 is the least, while the long-short portfolios deliver negative beta.

The CAPM style alpha, 3F and 4F alpha of $\mathrm{P} 1$ across size buckets are economically and statistically significant (see Table 16).

Table 15. Risk and return of large-cap, mid-cap and small-cap stocks sorted on historical volatility

\begin{tabular}{|c|c|c|c|c|c|c|}
\hline Key metrics & P1 (LV) & $\mathbf{P 2}$ & P3 & P4 & P5 (HV) & P1-P5 (LV-HV) \\
\hline \multicolumn{7}{|c|}{ LARGE-CAP } \\
\hline Excess returns & $6.18 \%$ & $4.50 \%$ & $0.63 \%$ & $-0.80 \%$ & $-19.00 \%$ & $25.17 \%$ \\
\hline Standard deviation & $17.75 \%$ & $24.12 \%$ & $28.09 \%$ & $31.27 \%$ & $43.78 \%$ & $33.29 \%$ \\
\hline Sharpe ratio & 0.35 & 0.19 & 0.02 & -0.03 & -0.43 & 0.76 \\
\hline Ex-post beta & 0.40 & 0.58 & 0.70 & 0.77 & 1.07 & -0.67 \\
\hline CAPM alpha & $8.22 \%$ & $7.51 \%$ & $4.24 \%$ & $2.85 \%$ & $-14.11 \%$ & $22.33 \%$ \\
\hline$t$-value & 3.09 & 2.39 & 1.26 & 0.72 & -2.50 & 3.98 \\
\hline \multicolumn{7}{|c|}{ MID-CAP } \\
\hline Excess returns & $6.48 \%$ & $0.25 \%$ & $1.35 \%$ & $-3.90 \%$ & $-17.46 \%$ & $23.94 \%$ \\
\hline Standard deviation & $21.50 \%$ & $27.05 \%$ & $30.40 \%$ & $35.81 \%$ & $45.14 \%$ & $30.43 \%$ \\
\hline Sharpe ratio & 0.30 & 0.01 & 0.04 & -0.11 & -0.39 & 0.79 \\
\hline Ex-post beta & 0.57 & 0.72 & 0.83 & 0.97 & 1.17 & -0.60 \\
\hline CAPM alpha & $9.32 \%$ & $3.80 \%$ & $5.16 \%$ & $0.46 \%$ & $-12.29 \%$ & $21.60 \%$ \\
\hline$t$-value & 4.52 & 1.49 & 1.96 & 0.15 & -2.53 & 4.14 \\
\hline \multicolumn{7}{|c|}{ SMALL-CAP } \\
\hline Excess returns & $5.98 \%$ & $2.69 \%$ & $-1.42 \%$ & $-9.14 \%$ & $-23.89 \%$ & $29.87 \%$ \\
\hline Standard deviation & $27.11 \%$ & $33.74 \%$ & $38.03 \%$ & $41.60 \%$ & $46.91 \%$ & $24.78 \%$ \\
\hline Sharpe ratio & 0.22 & 0.08 & -0.04 & -0.22 & -0.51 & 1.21 \\
\hline Ex-post beta & 0.77 & 0.97 & 1.10 & 1.19 & 1.32 & -0.55 \\
\hline CAPM alpha & $9.71 \%$ & $7.15 \%$ & $3.72 \%$ & $-3.62 \%$ & $-17.72 \%$ & $27.43 \%$ \\
\hline$t$-value & 7.00 & 4.95 & 2.67 & -1.89 & -5.85 & 7.22 \\
\hline
\end{tabular}

Note: The table reports annualized returns, annualized standard deviation, Sharpe ratio, ex-post beta and CAPM style alpha with its $t$-value. We created quintile portfolios by ranking stocks on their historical volatility of returns. P1 consists of lowvolatility stocks, while P5 consists of high-volatility stocks with each size bucket of large-cap, mid-cap and small-cap. 
Table 16. CAPM style alpha, three-factor alpha and four-factor alpha of volatility ranked portfolios within various size buckets

\begin{tabular}{|c|c|c|c|c|c|c|}
\hline & P1 (LV) & $\mathbf{P 2}$ & P3 & P4 & P5 (HV) & P1-P5 (LV-HV) \\
\hline \multicolumn{7}{|c|}{ LARGE-CAP } \\
\hline CAPM style alpha & $8.22 \%$ & $7.51 \%$ & $4.24 \%$ & $2.85 \%$ & $-14.11 \%$ & $22.33 \%$ \\
\hline$t$-value & 3.09 & 2.39 & 1.26 & 0.72 & -2.50 & 3.98 \\
\hline 3F alpha & $11.01 \%$ & $11.40 \%$ & $8.99 \%$ & $7.81 \%$ & $-6.39 \%$ & $17.40 \%$ \\
\hline$t$-value & 4.86 & 4.76 & 3.80 & 2.71 & -1.39 & 3.25 \\
\hline 4F alpha & $9.32 \%$ & $9.90 \%$ & $7.89 \%$ & $6.96 \%$ & $-6.86 \%$ & $16.18 \%$ \\
\hline$t$-value & 4.31 & 4.25 & 3.36 & 2.41 & -1.47 & 3.00 \\
\hline \multicolumn{7}{|c|}{ MID-CAP } \\
\hline CAPM style alpha & $9.32 \%$ & $3.80 \%$ & $5.16 \%$ & $0.46 \%$ & $-12.29 \%$ & $21.60 \%$ \\
\hline$t$-value & 4.52 & 1.49 & 1.96 & 0.15 & -2.53 & 4.14 \\
\hline 3F alpha & $10.68 \%$ & $6.95 \%$ & $8.37 \%$ & $3.96 \%$ & $-5.94 \%$ & $16.62 \%$ \\
\hline$t$-value & 5.31 & 3.08 & 3.65 & 1.45 & -1.39 & 3.35 \\
\hline 4F alpha & $9.94 \%$ & $6.28 \%$ & $8.36 \%$ & $3.73 \%$ & $-5.23 \%$ & $15.17 \%$ \\
\hline$t$-value & 4.95 & 2.77 & 3.60 & 1.34 & -1.21 & 3.04 \\
\hline \multicolumn{7}{|c|}{ SMALL-CAP } \\
\hline CAPM style alpha & $9.71 \%$ & $7.15 \%$ & $3.72 \%$ & $-3.62 \%$ & $-17.72 \%$ & $27.43 \%$ \\
\hline$t$-value & 7.00 & 4.95 & 2.67 & -1.89 & -5.85 & 7.22 \\
\hline 3F alpha & $9.20 \%$ & $6.38 \%$ & $1.86 \%$ & $-6.05 \%$ & $-20.62 \%$ & $29.82 \%$ \\
\hline$t$-value & 6.57 & 4.45 & 1.55 & -3.64 & -7.46 & 8.08 \\
\hline $4 \mathrm{~F}$ alpha & $8.99 \%$ & $6.42 \%$ & $1.97 \%$ & $-5.79 \%$ & $-19.92 \%$ & $28.91 \%$ \\
\hline$t$-value & 6.35 & 4.41 & 1.62 & -3.45 & -7.16 & 7.78 \\
\hline
\end{tabular}

Note: The table reports CAPM alpha, three-factor (Fama-French) alpha and four-factor (Fama-French-Carhart) alpha with their $t$-value of equally weighted portfolios formed by sorting on historical volatility of stock returns within large-cap, mid-cap and small-cap size buckets.

Table 17. Three-factor and four-factor regression coefficients of volatility ranked portfolios of largecap, mid-cap and small-cap stocks

\begin{tabular}{|c|c|c|c|c|c|}
\hline \multirow{2}{*}{ Size } & \multirow{2}{*}{ Factor loading } & \multicolumn{2}{|c|}{ P1 } & \multicolumn{2}{|c|}{ P5 } \\
\hline & & $3 F$ & $4 \mathrm{~F}$ & $3 F$ & $4 \mathrm{~F}$ \\
\hline \multirow{8}{*}{ LARGE-CAP } & EWI & 0.548 & 0.592 & 1.434 & 1.447 \\
\hline & $t$-value & 22.02 & 23.72 & 28.36 & 26.91 \\
\hline & $\mathrm{SMB}$ & -0.364 & -0.378 & -0.704 & -0.708 \\
\hline & $t$-value & -8.09 & -8.87 & -7.70 & -7.72 \\
\hline & $\mathrm{HML}$ & -0.168 & -0.179 & -0.520 & -0.523 \\
\hline & $t$-value & -5.00 & -5.62 & -7.61 & -7.63 \\
\hline & WML & - & 0.141 & - & 0.039 \\
\hline & $t$-value & - & 5.26 & - & 0.67 \\
\hline \multirow{8}{*}{ MID-CAP } & EWI & 0.638 & 0.658 & 1.436 & 1.417 \\
\hline & $t$-value & 28.92 & 28.39 & 30.62 & 28.49 \\
\hline & SMB & -0.128 & -0.134 & -0.351 & -0.345 \\
\hline & $t$-value & -3.21 & -3.39 & -4.13 & -4.06 \\
\hline & $\mathrm{HML}$ & -0.091 & -0.095 & -0.470 & -0.465 \\
\hline & $t$-value & -3.04 & -3.23 & -7.42 & -7.33 \\
\hline & WML & - & 0.062 & - & -0.059 \\
\hline & $t$-value & - & 2.48 & - & -1.11 \\
\hline \multirow{8}{*}{ SMALL-CAP } & EWI & 0.752 & 0.757 & 1.174 & 1.155 \\
\hline & $t$-value & 48.90 & 46.40 & 38.67 & 36.01 \\
\hline & $\mathrm{SMB}$ & 0.037 & 0.035 & 0.311 & 0.317 \\
\hline & $t$-value & 1.31 & 1.25 & 5.66 & 5.78 \\
\hline & $\mathrm{HML}$ & 0.036 & 0.035 & 0.187 & 0.191 \\
\hline & $t$-value & 1.75 & 1.68 & 4.55 & 4.67 \\
\hline & WML & - & 0.018 & - & -0.058 \\
\hline & $t$-value & - & 1.01 & - & -1.69 \\
\hline
\end{tabular}

Note: The table reports three-factor and four-factor regression coefficient analysis of extreme portfolios sorted on historical volatility within each size bucket - large-cap, mid-cap and small-cap. $5 \%$ significance is indicated in bold.

Stock price are adjusted for all corporate actions. 
An analysis of Table 17 reveals that P1 of largecap and mid-cap size buckets pick winner stocks, while the results are insignificant for P1 of smallcap size bucket on the momentum factor. The statistically significant results also reveal that extreme quintile portfolios formed on volatility sorts of large-cap and mid-cap size buckets picks growth stocks, while small-cap size bucket picks value stocks, but here the results are statistically insignificant.

\section{CONCLUSION AND FUTURE SCOPE}

The study provides strong evidence of the existence of low-volatility effect in the Indian equity market. Refuting the market efficiency theory, systematically investing in a portfolio of low-risk stocks deliver high returns than the benchmark index. We observe that within a particular asset class, it is possible to earn higher returns while taking low risk. To test the robustness of low-volatility effect across various size buckets, we controlled size using three methods, forming $5 \times 5$ independent size and volatility sorted portfolios (double sort), then again forming dependent volatility ranked portfolio controlled for size and later creating volatility ranked quintiles within each size bucket - large-cap, mid-cap and small-cap. We observe that the method of portfolio creation does not influence the low-volatility effect to deliver exceptionally high economical and statistically significant alpha. The alphas are positive and significant even after controlling for known factors like value and momentum. Thus, the empirical results reveal that low-volatility effect is an independent phenomenon and not an overlap of any of the established factors and is robust across size buckets. The portfolio of low-volatility stocks often picks growth and winner stocks. Investing in a portfolio of large-cap low-volatility stocks delivers the highest risk-adjusted returns than investing in a portfolio of mid-cap and small-cap low-volatility stocks. In future, the study can be conducted to observe the interaction of other established factors like value, momentum, profitability, investment, quality, short-term reversal, MAX with the low-volatility effect. This will help to study the existence or non-existence of the robustness of the low-volatility effect. We conclude with the claim that low-volatility effect is very strong and significant in the history of Indian capital markets and it will stay for a long time unless it becomes an overcrowded investment place. This can happen only if there is a change in the behavioral biases mentioned in literature explaining the perseverance of the low-volatility effect.

\section{REFERENCES}

1. Agarwalla, S. K. (2013). Four factor model in Indian equities market (Working Paper W.P. No. 2013-09-05). Indian Institute of Management, Ahmedabad. Retrieved from https://faculty. iima.ac.in/ iffm/Indian-FamaFrench-Momentum/ (accessed on December, 2018).

2. Ang, A., Hodrick, R., Xing, Y., \& Zhang, X. (2006). The Cross Section of Volatility and Expected Return. Journal of Finance, 61(1), 259-299. https://doi.org/10.1111/j.15406261.2006.00836.x

3. Baker, M., Bradley, B., \& Wurgler, J. (2011). Benchmarks as Limits to Arbitrage: Understanding the Low-Volatility Anomaly. Financial Analysts Journal, 67(1), 40-54. https://doi.org/10.2469/faj.v67.n1.4
4. Baker, N., \& Haugen, R. (2012). Low Risk Stocks Outperform within All Observable Markets of the World. Journal of Portfolio Management, 17(3), 35-40. Retrieved from https://papers.ssrn. $\mathrm{com} / \mathrm{sol} /$ papers.cfm?abstract $\mathrm{id}=2055431$

5. Bali, T. G., Cakici, N., \& Whitelaw, R. (2011). Maxing out: Stocks as lotteries and the cross-section of expected returns. Journal of Financial Economics, 99(2), 427446. https://doi.org/10.1016/j. jfineco.2010.08.014

6. Bali, T., \& Cakici, N. (2008). Idiosyncratic volatility and the cross section of expected returns. Journal of Financial and Quantitative Analysis, 43(1),
29-58. https://doi.org/10.1017/ S002210900000274X

7. Black, F., Jensen, M., \& Scholes, M. (1972). The Capital Asset Pricing Model: Some Empirical Tests. In Studies in the Theory of Capital Markets, edited by M. C. Jensen. New York: Praeger.

8. Blitz, D., \& Vliet, P. (2007). The Volatility Effect: Lower Risk Without Lower Return. Journal of Portfolio Management, 34(Fall), 102-113. Retrieved from https:// papers.ssrn.com/sol3/papers. cfm?abstract_id $=980865$

9. Blitz, D., Pang, J., \& Vliet, P. (2013). The Volatility Effect in Emerging Markets. Emerging Markets Review, 16, 31-45. 
Retrieved from https://papers.ssrn. com/sol3/papers.cfm?abstract_ $\mathrm{id}=2050863$

10. Carhart, M. (1997). On persistence in mutual fund performance. The Journal of Finance, 52(1), 57-82. https://doi. org/10.1111/j.1540-6261.1997. tb03808.x

11. Carvalho, R., Lu, X., \& Moulin, P. (2012). Demystifying Equity RiskBased Strategies: A Simple Alpha plus Beta Description. Journal of Portfolio Management, 8(3), 56-70. Retrieved from https:// www.hillsdaleinv.com/uploads/ Demystifying_Equity_RiskBased_Strategies,_A_Simple_Alpha_Plus_Beta_Description_Carvalho,_Lu,_Moulin.pdf

12. Centre for Monitoring Indian Economy (2018, December). Prowess Database.

13. Clarke, R., De Silva, H., \& Thorley, S. (2006). Minimum-Variance Portfolio in the U.S. Equity Market. The Journal of Portfolio Management, 33(1), 10-24. https:// doi.org/10.3905/jpm.2006.661366

14. Fama, E., \& French, K. (1992). The Cross-section of Expected Stock Returns. Journal of Finance,
47(2), 427-465. https://doi. org/10.1111/j.1540-6261.1992. tb04398.x

15. Frazzini, A., \& Pedersen, L. (2014). Betting Against Beta. Journal of Financial Economics, 111(1), 1-25. https://doi. org/10.1016/j.jfineco.2013.10.005

16. Haugen, R. A., \& Baker, N. L. (1991). The Efficient Market Inefficiency of Capitalizationweighted Stock Portfolios. Journal of Portfolio Management, 17(3), 35-40. https://doi.org/10.3905/ jpm.1991.409335

17. Haugen, R., \& Baker, N. (1996). Commonality in the Determinants of Expected Returns. Journal of Financial Economics, 41(3), 401-439. https://doi.org/10.1016/0304405X(95)00868-F

18. Haugen, R., \& Heins, A. (1975). Risk and the Rate of Return on Financial Assets: Some Old Wine in New Bottles. Journal of Financial and Quantitative Analysis, 10(5), 775-784. https:// doi.org/10.2307/2330270

19. Hong, H., \& Sraer, D. (2012). Speculative Betas (NBER working paper).
20. Joshipura, M., \& Peswani, S. (2017). Returns to Low Risk Investment Strategy. Applied Finance Letters, 6(1), 2-15.

21. Joshipura, M., \& Peswani, S. (2018). The Volatility Effect in Value and Growth Stocks: Evidence from India. NMIMS Management Review.

22. Martellini, L. (2008). Toward the Design of Better Equity Benchmarks: Rehabilitating the Tangency Portfolio from Modern Portfolio Theory. Journal of Portfolio Management, 34(4), 34-41. https:// doi.org/10.3905/jpm.2008.709978

23. Reserve Bank of India (2018, December). Financial Market' and sub-heading 'Government Securities Market. Retrieved from https:// www.rbi.org.in/Scripts/BS_ViewBulletin.aspx?Id=18378

24. Scherer, B. (2011). A Note on the Returns from Minimum Variance Investing. Journal of Empirical Finance, 18(4), 652-660. https://doi. org/10.1016/j.jempfin.2011.06.001

25. Shah, R. (2011). Understanding Low Volatility Strategies: Minimum Variance. Dimensional Fund Advisor. 